\title{
Colorectal Cancer pN1 TNM Finding v8
}

National Cancer Institute

\section{Source}

National Cancer Institute. Colorectal Cancer pN1 TNM Finding v8. NCI Thesaurus. Code C134170.

Colorectal cancer in which one to three regional lymph nodes are positive (tumor in lymph nodes measuring $0.2 \mathrm{~mm}$ or more), or any number of tumor deposits are present and all identifiable lymph nodes are negative. (from AJCC 8th Ed.) 